KS. GRZEGORZ LESZCZYŃSKI

Wydział Prawa Kanonicznego

Uniwersytetu Kardynała Stefana Wyszyńskiego w Warszawie

\title{
PROCEDURA REKURSU DO II SEKCJI SYGNATURY APOSTOLSKIEJ
}

Treść: - 1. Decyzja co do przyjęcia lub oddalenia rekursu. - 1.1. Faza wstępna czyli złożenie rekursu. - 1.2. Analiza wstępna. - 1.3. Decyzja Kongresu. - 2. Decyzja ostateczna Kolegium. - 3. Wykonanie i skutki decyzji II sekcji Sygnatury Apostolskiej.

Decyzje podejmowane przez II sekcję Sygnatury Apostolskiej dotyczą przyjęcia lub oddalenia rekursu oraz wydania ostatecznego wyroku rozstrzygającego spór administracyjny zostały określone Normach specjalnych z roku $1968 \mathrm{w}$ art. 97-126. W omawianiu procedury, która ma miejsce w postępowaniu przez II sekcję Sygnatury Apostolskiej należy wyróznić dwie kolejne fazy. Pierwsza kończy się decyzją Konkresu co do przyjęcia do procedury rekursu, druga zaś decyzją ostateczną Kolegium co legalności lub nielegalności zaskarżonego aktu.

\section{Decyzja co do przyjęcia lub oddalenia rekursu}

Faza pierwsza procedury, która ma miejsce w II sekcji Sygnatury Apostolskiej rozpoczyna się złożeniem rekursu. Następnie ma miejsce analiza wstępna rekursu, której dokonuje Sekretarz, w końcu zaś decyzja Kongresu co do przyjęcia rekursu do procedury lub jego oddalenia.

\subsection{Faza wstępna czyli złożenie rekursu}

Zgodnie z art. 104 Normae speciales Sygnatury Apostolskiej konieczne do wszczęcia postępowania jest wniesienie rekursu przez osobę 
pokrzywdzoną aktem administracyjnym ${ }^{1}$. W myśl art. 106 rekurs ten winien zawierać: imię, nazwisko i adres osoby wnoszącej, wskazanie zaskarżonego aktu lub dekretu, motywację faktyczną, podpis osoby wnoszącej lub patrona. Należy też załączyć kopię zaskarżonego aktu lub dekretu i wskazać datę otrzymania zawiadomienia o akcie czy dekrecie w celu zweryfikowania terminu 30 dni użytecznych, w czasie którym możliwe jest złożenie rekursu².

Rekurs co ważne, zgodnie z normą zawartą w art. $123 \S 1$ Konstytucji Pastor Bonus, może być złożony w czasie 30 dni użytecznych od dnia otrzymania dekretu wydanego przez Dykasterię rzymską lub przez nią potwierdzonego ${ }^{3}$. Wynika to również z art. $105 \S 1$ Norm specjalnych $^{4}$.

W przypadku rekursu od decyzji Dykasterii, która potwierdziła zaskarżony akt w drodze rekursu hierarchicznego, czas 30 dni należy liczyć od dnia zawiadomienia o dekrecie lub od 90 dnia, który upływa od dnia złożenia przez podmiot rekursu hierarchicznego do Dykasterii,

1 Art. 104 brzmi: „Ad obtinendam decisionem alterius sectionis Signaturae Apostolicae in controversiis de quibus agitur in art. 96, n. 1, opus est recursu, secundum communes normas processuales exarando".

2 Art. 106 brzmi: „Recursus inscribendus est alteri sectioni Signaturae Apostolicae et referre debet: 1) nomen et praenomen recurrentis, domicilium vel locum residentiae, necnon titulum, si reccurens non nomine proprio, sed qua repraesentans agit; 2) actum seu decretum administrativum quod impugnatur, et diem acceptae notificationis ad normam iuris; 3) summariam factorum expositionem, rationes quibus nititur recursus, leges quae violatae asseruntur et conclusione; 4) subscriptionem parties recurrentis, vel Patroni mandato speciali instructi et, in altero casu, eiusdem mandate notas (estremi), nisi ad calcem ipsius recursus mandatum sit collatum".

3 Art. 123 § 1 Pastor Bonus brzmi: „Praeterea (Supremum Signaturae Apostolicae Tribunal) cognoscit de recursibus, intra terminum peremptorium triginta dierum utilium interpositis, adversus actus administrativos singulars sive a Dicasteriis Curiae Romanae latos sive ab ipsis probatos...".

${ }^{4}$ Art. $105 \S 1$ Norm specjalnych brzmi: „Recursus Cancellariae exhibendus est intra terminum peremptorium triginta dierum a die qua decreta vel acta quae impugnatur notificata sunt, vel a die qua constet reccurrentem revera illa a normam iuris novisse; sin minus, intra eundem terminum peremptorium, recursus tradendus est officio publici cursus ut ad Cancellariam transmittatur, ea quidem ratione ut exhibeatur syngrapha authentica receptionis cum certa adnotatione diei". 
na który Dykasteria nie odpowiedziała, a zatem zastosowano milczenie równoznaczne z odpowiedzią negatywną. Warto jedynie dodać, że zgodnie z art. 120 § 2 Regulaminu Ogólnego Kurii Rzymskiej z roku 1999, jeśli Dykasteria nie jest w stanie wydać decyzji w ciągu trzech miesięcy, winna o tym powiadomić osobę zainteresowaną. Powiadomienie to zawiesza prawo do złożenia rekursu do II sekcji do dnia wyznaczonego przez Dykasterię lub do dnia wydania ostatecznej decyzji.

W przypadku rekursu od decyzji Dykasterii, która wydała dekret, nie będący dekretem hierarchicznym, termin 30 dni należy liczyć od dnia zawiadomienia o odpowiedzi negatywnej na prośbę złożoną do Dykasterii, zgodnie z kan. 1734 lub od 30 dnia, który upływa od dnia złożenia przez podmiot prośby, o której mowa w kan. 1734 KPK, na którą Dykasteria nie odpowiedziała, a zatem zastosowano milczenie równoznaczne $\mathrm{z}$ odpowiedzią negatywną.

Tak jednoznacznie określony termin, w którym możliwe jest złożenie rekursu do II sekcji Sygnatury Apostolskiej wymaga jednak sprecyzowania w odniesieniu do rozumienia sformułowania dni użytecznych, które nie zawsze jest jednoznaczne. Jak zauważa G.P. Montini, niektóre rekursy pochodzące z terenu Stanów Zjednoczonych, składane są do II sekcji Sygnatury Apostolskiej w czasie 30 dni użytecznych, które to dni jednak interpretowane są nie zgodnie z normą zawartą w Kodeksie Prawa Kanonicznego, ale zgodnie z cywilnym orzecznictwem amerykańskim. W myśl bowiem obowiązującej w tymże orzecznictwie procedury do dni użytecznych nie zalicza się ani niedzieli, ani jakiegokolwiek innego dnia wolnego od pracy. Oznacza to, że w praktyce określony czas 30 dni na złożenie rekursu może być, zgodnie z przyjętym sposobem liczenia dni użytecznych, rozciągnięty na okres o wiele dłuższy. Co ważne taki sposób przyjęcia liczenia dni użytecznych, niezgodny z normą kodeksową, powoduje, że rekursy te wpływają do Sygnatury Apostolskiej po terminie, w którym możliwe jest ich złożenie 5 .

${ }^{5}$ G.P. Montini, I ricorsi amministrativi presso il supremo tribunale della segnatura apostolica, w: I giudizi nella Chiesa. Processi e procedure speciali, Milano 1999, s. 95. 
Zgodnie z kan. $201 \S 2$ KPK czas użyteczny należy rozumieć, że wykonującemu lub dochodzącemu swego prawa tak przysługuje, iż dla nie wiedzącego albo nie mogącego działać nie płynie ${ }^{6}$. Dlatego też czasami rekursy, które składane są do Sygnatury Apostolskiej po terminie 30 dni od zawiadomienia o decyzji Dykasterii usprawiedliwiane są brakiem wiedzy co do samego terminu skladania rekursu albo organu, do którego możliwe jest jego złożenie. Należy zatem w tym miejscu przypomnieć, co czyni również Sygnatura Apostolska, że zgodnie z normą zawarta w kan. 15 § 2 nie domniemywa się ignorancji lub błędu co do faktu własnego ${ }^{7}$, zatem, aby ignorancja była przyczyną usprawiedliwiającą przekroczenie terminu złożenia rekursu, należy udowodnić, iż nie wynika ona z zaniedbania osoby zainteresowanej ${ }^{8}$. Obowiązek udowodnienia ignorancji spoczywa na autorze rekursu' ${ }^{9}$.

Złożenie rekursu może wywoływać zarówno skutek przekazujący (effectus devolutivus), jak i zawieszający (effectus suspensivus). Jak już zauważono, omawiając kwestię dotyczącą rekursu hierarchicznego, skutek przekazujący polega na przejęciu kompetencji nad zaskarżonym aktem administracyjnym przez organ, do którego został złożony rekurs, a zatem w tym przypadku przez II sekcję Sygnatury Apostolskiej. Skutek zawieszający polega na zakazie wykonania aktu oraz wprowadzania jakichkolwiek zmian do zaskarżonego aktu od mo-

${ }^{6}$ Kan. $201 \S 2$ brzmi: „Tempus utile intellegitur quod ita ius suum exercenti aut persequenti competit, ut ignoranti aut agree non valenti non currat".

${ }^{7}$ Kan. 15 § 2 brzmi: „Ignorantia vel error circa legem aut poenam aut circa factum proprium aut circa factum alienum notorium non praesumitur:...".

${ }^{8}$ Por. coram Augustoni, 4 maja 1996, DE 108, 1997, II, n. 8, s. 14. Czytamy tutaj: „,...Ignorantia circa legem non praesumitur et tantummodo excusat si verisimilis est et nullam admittit negligentiae notam. Concedimus igitur ignorantiam termini peremptorii utilis ipsa lege statuti facilius haberi posse apud rudes christifideles. Quaestio autem est utrum ipsi tempestive a perito in iure canonico vel a competenti auctoritate opportunas notitias in re exquisiverint, necne. Apta enim diligentia necessario requiritur, quia secus termini peremptorii utiles simplices fideles perraro urgerent, facile pessumdatis legibus quae terminos peremptorios statuunt”.

9 Por. tamże, n. 11, s. 15. Czytamy tutaj: „In casu recurrentes ad rem minime demostraverunt absentiam cuiusvis negligentiae". 
mentu zawieszenia wykonania aktu do czasu wydania decyzji przez Trybunał Sygnatury Apostolskiej.

Wniesienie przez osobę zainteresowaną rekursu do II sekcji Sygnatury Apostolskiej zawsze wywołuje skutek przekazujący ${ }^{10}$. Rekurs wywiera natomiast skutek zawieszający w tych wypadkach, w których prawo określa taki skutek dla rekursu hierarchicznego ${ }^{11}$. Należy w tym miejscu przypomnieć, iż Kodeks Prawa Kanonicznego wskazuje na trzy takie przypadki: rekurs od dekretu wydalającego członka instytutu życia konsekrowanego, instytutu świeckiego lub stowarzyszenia życia apostolskiego $^{12}$, rekurs od dekretu, w którym została wymierzona lub zdeklarowana kara $^{13}$ oraz rekurs od dekretu usunięcia proboszcza ${ }^{14}$. We wszystkich innych przypadkach prawo nie przewiduje skutku zawieszającego ex iure.

Reguła pozwalająca zastostosować normy dotyczące rekursu hierarchicznego per analogiam do rekursu składanego do II sekcji Sygnatury Apostolskiej, w odniesieniu do skutku zawieszającego wykonanie aktu administracyjnego, została potwierdzona przez Papieską Komisję Interpretacyjną Dekretów Soboru Watykańskiego II ${ }^{15}$ oraz przez praktykę Trybunału Sygnatury Apostolskiej ${ }^{16}$.

${ }^{10}$ Por. F. SAlerno, Il giudizio presso la «Sectio Altera» del S.T. della Segnatura Apostolica, w: La giustizia amministrativa nella Chiesa, Città del Vaticano 1991, s. 162.

${ }^{11}$ Por. J. Krukowski, Administracja w Kościele. Zarys kościelnego prawa administracyjnego, Lublin 1985, s. 234.

${ }^{12}$ Por. kan. 700, 729, 746 KPK.

${ }^{13}$ Por. kan. 1353, 1342 § 2, 1720 KPK.

${ }^{14}$ Por. kan. 1747 \& 3 KPK.

${ }^{15}$ Por. Pontificia Commissio Decretis Consilit Vaticani II Interpretandis, Responsum, AAS 63, 1971, s. 860.

${ }^{16}$ Por. I. Gordon, Z. GrocholewsKi, Documenta recentiora circa rem matrimonialem et processualem cum notis bibliographicis et indicibus, Roma 1977, s. 400-401; A. Ranaudo, Questiones quaedam controversae circa Sectionem Alteram Signaturae Apostolicae, Periodica 67, 1978, s. 673. Ten ostatni pisze: „Analogice enim cum processu iudiciali, etiam in processu administrativo servandum est principium: lite pendente, nihil innovetur... Siquidem a definitio decreto Ordinarii recursus ad Sedem Apostolicam ut unicum datur iuris remedium, hoc remedium effectum in processu administrativo similem illi, quem recursus seu appelatio in processu iudiciali, obtinet, nempe in suspensivo quoad attributionem iuris quod in controversia est". 
Zawieszenie wykonania aktu, oprócz przypadków wskazanych ex iure może również nastąpić w wyniku decyzji II sekcji Sygnatury Apostolskiej, na prośbę złożoną przez autora rekursu. Wynika z normy zawartej w art. 108 Normae speciales, w myśl którego Sygnatura Apostolska ma kompetencje wydania decyzji zawieszającej wykonanie aktu administracyjnego, o ile poważne motywy i dokumenty, w ocenie samej II sekcji, taką decyzję uzasadniają ${ }^{17}$. Zdaniem R. Coppola poważne motywy, o których mowa w art. 108 odnoszą się przede wszystkim do szkody, jaką mógłoby wyrządzić wykonanie zaskarżonego aktu oraz do niemożności, w razie decyzji odwołującej akt, przywrócenia sytuacji pierwotnej ${ }^{18}$.

Prośba o zawieszenie wykonania aktu administracyjnego staje się przedmiotem sprawy wpadkowej, którą Sygnatura Apostolska rozstrzyga według procedury i w terminie określonym w art. $113 \S 1$ 1-4 Norm specjalnych. Sprawa ta może być rozpoczęta przez Kardynała Prefekta, który po wysłuchaniu Sekretarza, Promotora sprawiedliwości i innych członków Kongresu, zawiadamia organ administracyjny, który wydał zaskarżony akt, jak i autora prośby, aby w ciągu 30 dni wyznaczyli oni swego adwokata i pełnomocnika oraz przedstawili dokumenty i opinie mające wartośc w odniesieniu do przedmiotu decyzji. Po upływie 30 dni sekretarz Sygnatury przesyła wszytkie akta, w tym tzw. positio Promotorowi sprawiedliwości z prośbą o przestawienie jego votum w ciągu 10 dni od dnia otrzymania positio. W każdym razie Kongres winien podjąć decyzję co do zawieszenia wykonania zaskarżonego aktu administracyjnego w ciągu 60 dni od dnia otrzymania prośby o jego zawieszenie. W przypadku decyzji nadającej skutek zawieszający wykonaniu aktu, Sekretarz zawiadamia o tym expeditissime tramie kompetentny organ administracyjny w celu zawieszenia wykonania aktu ${ }^{19}$.

${ }^{17}$ Art. 108 brzmi: „Recursui adnecti potest instantia, allatis motivis gravibus vel documentis quibus innitur, ad obtinendam suspensionem exsecutionis actus impugnati”.

${ }^{18}$ Por. R. Coppola, L'effetto sospensivo nel processo davanti alla Sectio Altera Della Segnatura Apostolica, w: La giustizia nell'attività amministrativa della Chiesa: il contenzioso amministrativo, Milano 2006, s. 348.

19 Por. Normae speciales, art. 113 § 1-4. 
Należy pamiętać, co podkreśla P.V. Pinto, że w kanonicznym prawie administracyjnym skutek przekazujący jest zasadą, zaś ten zawieszający jedynie wyjątkiem. Nie oznacza to jednak, że ten drugi nie ma wymiaru praktycznego, gdyż w odniesieniu do wykonania aktu administracyjnego do czasu wydania ostatecznej decyzji zawiesza jego skutki ${ }^{20}$.

\subsection{Analiza wstępna}

Ocena elementów formalnych rekursu we wstępnej fazie procedury, jaka toczy się w II sekcji Sygnatury Apostolskiej, należy do Sekretarza. To on ocenia, czy rekurs zawiera wszystkie konieczne elementy, czy też jest wadliwy lub nieważny.

W myśl art. 107 § 1 Norm specjalnych rekurs może być nieważny z powodu braku podpisu osoby wnoszącej rekurs lub jej patrona, jak i ówczas, gdy ma miejsce absolutna niepewność co do przedmiotu rekursu ${ }^{21}$. Jeśli rekurs zawiera braki, które można poprawić sekretarz Sygnatury wyznacza termin zawity na uzupełnienie braków i przedstawienie poprawionego rekursu ${ }^{22}$. Jeśli w wyznaczonym terminie rekurs nie zostanie przedstawiony sekretarz odrzuca go a limine jako nie do przyjęcia.

Warto zauważyć, że jakkolwiek norma zawarta w art. 107 Norm specjalnych określa przypadki, w których rekurs może być odrzucony, to jednak praktyka Sygnatury Apostolskiej wskazuje, iż nie są to jedyne możliwe motywy odrzucenia rekursu. Jak zauważa F. D’Ostilio, rekurs może być odrzucony jeśli podmiot czynny rekursu zdolności procesowej lub pomimo jej posiadania nie ma interesu osobistego, aktualnego i bezpośredniego dla przedstawienia rekursu. Ponadto może mieć to miejsce jeśli nie została wydana w konkretnej sprawie decyzja Dykasterii rzymskiej albo podmiot ma intencję zaskarżenia części merytorycznej rozstrzygnięcia nie zaś jego legalności in procedendo albo in decernendo ${ }^{23}$.

\footnotetext{
${ }^{20}$ Por. P.V. PInTo, Diritto amministrativo canonico, Bologna 2006, s. 374.

${ }^{21}$ Art. $107 \S 1$ brzmi: ,Recursus est nullus: 1) si desit subscriptio requisita articulo praecedenti, n. 4; 2) si absolute incertum maneat de quibusnam personis vel de quonam obiecto in recursu agatur".

${ }^{22}$ Por. Normae speciales, art. $107 \S 2$.

${ }^{23}$ Por. F. D’Ostilio, Il diritto amministrativo della Chiesa, Città del Vaticano 1996, S. 514.
} 
Jeśli sekretarz primo ictu oculi uzna, że rekurs nie spełnia wymogów stawianych rekursowi, jaki może być przedstawiony II sekcji Sygnatury Apostolskiej ma prawo zastosować reiectio a limine ${ }^{24}$. Przeciw takiej decyzji osoba wnosząca rekurs może odwołać się do Kongresu ${ }^{25}$.

Jeśli sekretarz stwierdzi, ze rekurs jest prawidłowo zredagowany zawiadamia organ administracyjny, który wydał lub potwierdził zaskarżony akt, jak i wszystkich zainteresowanych rekursem oraz wzywa ich, by w terminie 30 dni przedstawili dokumenty potwierdzające ich racje ${ }^{26}$. $\mathrm{W}$ tej fazie konieczne jest udzielenie mandatów patronom stron ${ }^{27} . \mathrm{Na}$ tym etapie procedury strony osobiście lub za pośrednictwem Patronów mogą przedstawiać dokumenty i argumenty na poparcie swojej tezy ${ }^{28}$.

${ }^{24}$ Por. Z. Grocholewski, La «Sectio Altera» della Segnatura apostolica con particolare riferimento alla procedura in essa seguita, Apollinaris 54, 1981, s. 96-97.

${ }^{25}$ Por. Z. Grocholewski, Iustitia administrativa ecclesiastica. Subsidia ad usum studentium, Città del Vaticano 1990, s. 93; G.P. MonTINI, I ricorsi amministrativi presso il supremo tribunale della segnatura apostolica, w: I giudizi nella Chiesa. Processi e procedure speciali, Milano 1999, s. 93-94. G.P. Montini zauważa, że wada rekursu, która staje się przyczyna jego oddalenia a limine winna być poważnej natury i ewidentna. Co ważne, nalezy zawsze zagwarantować autorowi rekursu oddalonego a limine, prawo zaskarżenia tej decyzji do Kongresu. W przeciwnym wypadku prawo do wniesienia rekursu przynależne każdej osobie nie zostałoby zachowane.

${ }^{26}$ Art. 112 brzmi: „Ubi primum recursus cum documentis necessariis ad Cancellariam pervenerit, Secretarius curet ut communicetur cum Auctoritate ecclesiastica quae decisionem impugnatam tulit, necnon cum aliis quorum interest se opponere; exquirat a competente Auctoritate ecclesiastica ut acta omnia et documenta spectantia ad casum, de quo controvertitur, transmittat intra terminum peremptorium triginta dierum a recepta communicatione; inyitet omnes quorum ex adverso interest ud exhibendum eventualem oppositum recursum vel ad deporendas responsiones et ud exhibenda acta et documenta pro sua quisque parte, intra terminum pariter triginta dierum; demum ud deponendam pecuniae summam, similiter ac statutum est art. 109, n. 5".

${ }^{27}$ Art. 1141 brzmi: „Si mandatum a recurrente conferatur Patrono post exhibitum penes Cancellariam Signaturae Apostolicae recursum, sed ante elapsum terminum pro exhibitione actorum et documentorum de quibus in art. 112, Patronus impetrare potest a Secretario terminum computandum ab accepto mandato, vel ab eius notitia, si ipsum mandatum directe transmissum fuerit Cancellariae, ut exhibeat tum restrictum defensionalem ad illustrandum vel etiam, si casus ferat, ad emendandum recursum porrectum a parte, tum nova documenta quae forte censeat utilia pro recurrentis defensione".

${ }^{28}$ Art. $114 \S 2-3$ brzmi: „§ 2. Semper vero fas est recurrenti petere a Secretario facultatem porrigendi ulteriorem scripturam memorialem ad declarandum vel emen- 
Po złożeniu nowych dokumentów strony, które są w opozycji mają prawo w termienie 20 dni przedłożyć swoje kontrargumenty ${ }^{29}$.

Po upłynięciu określonych terminów, w których strony mogą przedstawiać swoje kontrargumenty akta procesowe zostają przesłane Promotorowi sprawiedliwości, ewentualnie jednemu z wotantów lub referendarzy, który w terminie 30 dni, licząc od momentu otrzymania akt, przygotowuje wotum pro rei veritate ${ }^{30}$. Wotum promotora zostaje następnie zakomunikowane stronom, które mogą odpowiedzieć na nie $\mathrm{w}$ ciągu 10 dni od daty otrzymania zawiadomienia ${ }^{31}$.

dandum recursum, licet a Patrono exhibitum vel subsignatum, post quam inspexerit positionem et documenta, sive ex officio sive pro parte, oblata ad normam praecedentis art. $112 \mathrm{ab}$ Auctoritate ecclesiastica et a quovis alio cuius interest se opponere. § 3. In huiusmodi scriptura memoriali recurrens potest proponere quoque additas rationes seu motiva recursus, quae quidem deduxerit, ex inspectis documentis et actis vel collectis ex officio vel productis a parte et ut supra depositis; itemque instare potest ut facultas ipsi fiat exhibendi ulteriora documenta in sui defensionem, quae necessaria visa sint post deposita acta et documenta, vel cx officio vel pro parte. Haec autem omnia perficienda sunt intra terminum triginta dierum ex quo Cancellaria communicaverit deposita esse acta ula et documenta".

${ }^{29}$ Art. $114 \S 4$ brzmi: „Partes resistentes jus habent obiciendi vel pro ponendi contrarium recursum, necnon exhibendi ulteriora documenta, ad refutanda ea quae recurrens produxit, intra terminum viginti dierum a accepta notitia novarum deductionum vel documentorum ex parte recurrentis".

${ }^{30}$ Art. $115 \S 1-2$ brzmi: „§ 1. Expiratis terminis ad exhibenda defensiones vel scripta memorialia partium, Secretarius tradit omnia acta processus Promotori Iustitiae, ut hic votum promat pro rei veritate. Quod si ob molem laboris Promotor Iustitiae impar sit voto ferendo intra terminum de quo in sequenti paragrapho, potest Secretarius, petente in scriptis ipso Promotore Iustitiae, munus conferre singulis in casibus alicui ex Votantibus vel ex Referendariis Signaturae Apostolicae. § 2. Promotor Iustitiae, sive ordinarius sive ad casum deputatus, votum suum pro rei veritate apud Cancellariam deponere tenetur intra triginta dies ab acceptis actis processus...".

${ }^{31}$ Art. $115 \S 2$ brzmi: ,...Quod votum Secretarius suo decreto cito communicet cum partibus in causa, quae respondere possunt intra terminum decem dierum ab accepta communicatione". 


\subsection{Decyzja Kongresu}

Po zakończeniu fazy przedstawiania dowodów i argumentów, rekurs winien być rozpatrzony przez Kongres II Sekcji Sygnatury Apostolskiej, w którym uczestniczy kardynał prefekt, sekretarz, promotor sprawiedliwości oraz ewentualnie niektórzy z wotantów lub referendarzy. Kongres, jak słusznie zauważa F. Salerno, nie ma jednak struktury kolegialnej, a decyzje w nim zapadające należą wyłącznie do Kardynała Prefekta ${ }^{32}$. Stąd decyzję o przyjęciu lub odrzuceniu rekursu jako bezpodstawnego podejmuje w terminie 20 dni osobiście Kardynał Prefekt ${ }^{33}$.

Podczas Konkresu, na prośbę Kardynała Prefekta, swoją opinię, ustnie lub na piśmie, przedstawia Promotor sprawiedliwości, w której ukazuje motywy faktyczne i prawne rekursu, ocenia przedstawione przez podmioty argumenty oraz wystawia swoje votum pro rei veritate. Po wystąpieniu Promotora sprawiedliwości Sekretarz i inni członkowie Kongresu mający takie prawo, przedstawiają swoją opinię co do votum Promotora sprawiedliwości. Jeśli jest to konieczne, następuje krótka dyskusja. Po niej zaś Kardynał Prefekt, biorąc pod uwagę wszytkie opinie i zgromadzony materiał sprawy wydaje decyzję do przyjęcia lub odrzucenia rekursu ${ }^{34}$.

\footnotetext{
${ }^{32}$ Por. F. SAlerno, dz. cyt., s. 163.

${ }^{33}$ Art. 116 brzmi: „Post quam, curante Cancellariae Praeposito, distributae fuerint omnes scripturae de quibus in praecedentibus articulis, Cardinalis Praefectus. intervenientibus Secretario, Promotore Iustitiae et Subsecretario, intra terminum viginti dierum decernit utrum recursus admittendus sit ad disceptationem, an reiciendus quia manifeste ipse caret fundamento. Contra decretum reiectionis, datur recursus ud Collegium iudicans, intra terminos iure canonico statutos. Decisio Collegii nulli impugnationi est obnoxia".

${ }^{34}$ Por. F. D’Ostilio, dz. cyt., s. 519. Autor zauważa, że podstawowym zadaniem Kongresu jest zbadanie czy przedstawiony rekurs zawiera podstawy prawne czy też ewidentnie jest ich pozbawiony. W pierwszym przypadku Kongres podejmuje decyzję co do przyjęcia rekursu, w drugim zaś co do jego oddalenia. Zbadanie podstawy prawnej rekursu ma miejsce, o ile Kongres posiada pewność co do elementów podstawoych rekursu, podmiotowych i przedmiotych, których zawartość bada wcześniej Sekretarz i Kanclerz Sygnatury.
} 
Podejmując decyzję kardynał prefekt bierze pod uwagę nie tylko fundament prawny rekursu, ale również zgodnie z praktyką Sygnatury Apostolskiej, pomimo dokonanej już wstępnej oceny, jego elementy istotne, do których zalicza się np. zdolność procesową i legitymizację osoby wnoszącej rekurs, jak i przedmiot, petitum rekursu oraz causa petend $i^{35}$. Brak któregoś z elementów esencjalnych może stanowić podstawę odrzucenia rekursu. Decyzja Kongresu winna być podana do wiadomości stron. Przeciwko decyzji Kongresu odrzucającej rekurs osoba wnosząca go może w terminie 10 dni odwołać się do Kolegium, którego decyzja nie może być zaskarżona ${ }^{36}$.

Warto w tym miejscu zauważyć, że zdaniem Z. Grocholewskiego, przy ewidentnym braku jakiegoś przymiotu czy elementu istotnego rekursu, decyzję co do jego odrzucenia mógłby podjąć expedittissime Sekretarz ${ }^{37}$. Nie zgadza się z taką opinia P.V. Pinto, który twierdzi, że decyzja podejmowana przez Konkres, o której mowa w art. 116 Norm specjalnych Sygnatury Apostolskiej, nie sprowadza się wyłącznie do czystej analizy dokumentów, ale ma wymiar o wiele szerszy. Stąd nie jest kompetencją Sekretarza dokonanie analizy i wydanie decyzji, o której mowa ${ }^{38}$.

Przyjęcie rekursu oznacza, że istnieją argumenty prawne i faktyczne wskazujące na to, że miało miejsce naruszenie prawa przez określony akt administracyjny, a zatem istnieje wątpliwość, której wyjaśnienie nastąpi w drodze postępowania procesowego. Głównym zadaniem zatem Kongresu jest ustalenie czy przedstawiony rekurs ma fundament prawny i faktyczny. Decyzja Kardynała Prefekta co do przyjęcia lub odrzucenia rekursu, pozwala uniknąc przekazywania do dalszej procedury rekursów, które pozbawione są fundamentu prawnego i fak-

\footnotetext{
${ }^{35}$ Por. Z. Grocholewski, Iustitia administrativa, dz. cyt., s. 92-93.

${ }^{36}$ Por. Normae speciales, art. 116.

${ }^{37}$ Por. Z. Grocholewski, La Sectio Altera, dz. cyt., s. 96-97.

${ }^{38}$ Por. P.V. PINTo, dz. cyt., s. 377. Autor pisze: „Mi sembrerebbe troppo, perché si tratta di una valutazione che va al di là di una semplice verifica documentale. Riteniamo perciò che le norme potrebbero prevedere questa eventualità, ma già prima dell'art. 115 (attuale); cioè precedentemente alla procedura per il Congresso. Non dovrebbe essere una decisione expeditissime; contro di esse possibilità di ricorso al Card. Prefetto, che, quale giudice nato del Tribunale Supremo, decide expeditissime".
} 
tycznego. Racją normy zawartej w art. 116 Norm specjalnych są zatem względy natury czasowej, ekonomicznej, ale też szacunku względem organu administracyjnego.

Należy zauważyć, co czyni G.P. Montini, że decyzja Kongresu, z racji na rzetelnosć procedury, może czasem przybierać znamiona decyzji antycypującej ostateczną decyzję Kolegium i dlatego w jej podejmowaniu należy zachować wyjątkową ostrożność, tak aby była to rzeczywiście decyzyzja co do fundamentu rekursu, nie zaś co do legalności samego zaskarżonego aktu administracyjnego ${ }^{39}$. Błędna interpretacja uprawnień Kongresu mogłaby doprowadzić do mylnego przekonania o wyższości decyzji, którą podejmuje Kongres nad tą, która w ostatecznosci orzeka o legalności czy nielegalności aktu administracyjnego, a która przynależy do Kolegium ${ }^{40}$.

\section{Decyzja ostateczna Kolegium}

W drugim etapie postępowania jest zadaniem sekretarza Sygnatury Apostolskiej zwołanie w ciągu 30 dni od przyjęcia rekursu Patronów lub ewentualnie samych stron w celu określenia wątpliwości, na którą należy odpowiedzieć wydając decyzję ostateczną ${ }^{41}$. Określenie tejże wątliwości jest z oczywistych względów głównym motywem wezwania Patronów i ewentualnie stron, nie jest jednak jedynym. W trakcie dyskusji bowiem winno nastąpić doprecyzowanie motywu rekursu, tj. konkretne określenie normy, która zdaniem autora rekursu została

\footnotetext{
${ }^{39}$ Por. G.P. Montini, dz. cyt., s. 100-101.

${ }^{40}$ Por. G. LoBIna, De processibus administrativae indolis in dimissione religiosorum et in amotione parochorum, Periodica 67, 1978, s. 685. Autor pisze: „Congressus id tantum praestare deberet, ut inquisitionem perageret circa solas condiciones requiditas ad validam admissionem recursus: ut sunt ...legitimi termini, validitas libelli, exemptio a defectibus insanabilibus, legitimatio ad agendum, definitiva indoles decreti ...graevis pronuntiatio soli Cardinalium Collegio esset reservanda, actio autem Congressus continenda esset intra fines merae probationis praeviae, secluso iudicio".

${ }^{41}$ Art. $117 \S 1$ brzmi: „Intra terminum triginta dierom ad admissione recursus, Secretarius, convocat partes earumve Patronos ad summariam delibationem oralem processus, in qua necessarias declarationes petit, indicato quaestiones quae ex officio colligi posse et opportune tractandas conseat; quaestiones praeiudiciales et Fundamentals praefinit et proprios controversiae terminos statuit".
} 
naruszona, jak i wskazanie faktów, która mają w szczególny sposób poświadczać motyw podmiotowy, a więc to, o co prosi autor rekursu II sekcję Sygnatury Apostolskiej. Doprecyzowanie, które ma miejsce podczas dyskusji, jest zdaniem F. D’Ostilio nie tylko użyteczne, ale też konieczne, zwłaszcza w kontekście dalszego postępowania i możliwego zarządzenia uzupełnienia materiału dowodowego ${ }^{42}$.

Po dyskusji zatem sekretarz może zarządzić dodatkowe postępowanie dowodowe lub zarządać nowych dokumentów, po zakończeniu którego strony prezentują swoje ostateczne oświadczenia ${ }^{43}$. Należy w tym miejscu dodać, że w myśl art. 117 § 3 Norm specjalnych, Kardynał Prefekt może zasięgnąć opinii jakiegoś eksperta w dziedzinie prawa administracyjnego, odznaczającego się szczególnymi zaletami o charakterze moralnym i religijnym ${ }^{44}$.

Praktyka II sekcji Sygnatury Apostolskiej wskazuje, że również Promotor sprawiedliwości, zanim nastąpi posiedzenie Kolegium, na piśmie przedstawia swoje votum pro rei veritate ${ }^{45}$. Warto zauważyć, że normy specjalne przewidują votum ustne promotora $\mathrm{w}$ trakcie posiedzenia Kolegium ${ }^{46}$. Przyjął się też zwyczaj przesyłania opinii Promotora sprawiedliwości patronom stron, którzy jeśli uznają to za stosowne mogą do nich się ustosunkować. Jeśli odpowiedź Patronów stron nastąpi, Sekretarz przesyła ją do Promotora sprawiedliwości, który może z kolei do nich się ustosunkować lub potwierdzić swoje votum ${ }^{47}$.

\footnotetext{
${ }^{42}$ Por. F. D’Ostilio, dz. cyt., s. 524.

${ }^{43}$ Art. 118 brzmi: „Intra terminum triginta dierum a convocatione partium, de qua agit $\S 1$ superioris articuli, - si nimirum nullum statutum sit supplementum instructionis, neque requisitum votum consultivum de quo in $\S 3$ eiusdem articuli - vel intra terminum triginta dierum ab accepta notificatione de depositis apud Cancellariam suppletis documentis et investigationibus atque voto consultivo de quibus in $\S \S 2-3$, recurrens debet, sua cura et sumptu, apud Cancellariam deponere tot exemplaria summarii processus quot Secretarius constituerit. Ius est partibus intra eumdem terminum deponere restrictum conclusivum in quo contineantur omnia petita, etiam ordinis instructorii, et complete evolvantur rationes, sive in facto sive in iure, quibus ipsa petita nituntur".

${ }^{44}$ Por. Normae speciales, art. $117 \S 3$.

${ }^{45}$ Por. Z. Grocholewski, La Sectio Altera, dz. cyt., s. 107.

${ }^{46}$ Por. Normae speciales, art. $120 \S 2$.

${ }^{47}$ Por. F. D’Ostilio, dz,. cyt., s. 526.
} 
Posiedzenie Kolegium ma odbyć się w ciągu 60 dni od dnia, w którym odbyła się dyskusja lub nastąpiło zawiadomienie stron o zakończeniu postępowania dowodowego uzupełniającego ${ }^{48}$. W posiedzeniu zwykle bierze udział 5 kardynałów, z tym ze kardynał prefekt może zarządzić, że dana sprawa będzie rozstrzygana przez „,pełną Sygnaturę”. W trakcie posiedzenia Kolegium najpierw Kardynał ponens lub relator w skrócie przedstawia racje obu stron oraz zebrany materiał dowodowy. Po jego relacji Normy specjalne przewidują krótkie przedstawienie swojej opinii przez Promotora sprawiedliwości, ale praktyka Sygnatury Apostolskiej wskazuje, że skoro Promotor swoje votum przedstawia na piśmie przed posiedzeniem Kolegium, stąd w trakcie jego trwania każdy z członków Kolegium dysponuje integralnym tekstem.

Normy specjalne Sygnatury Apostolskiej przewidują taką ewentualność, że Kolegium może odłożyć wydanie decyzji rozstrzygającej spór lub wydać rozstrzygnięcie jedynie częściowe, ustalając jakie jeszcze uzupełnienie materiału dowodowego należy przeprowadzić ${ }^{49}$.

Decyzja Kolegium odpowiada na petitum podmiotu czynnego rekursu, w szczególności zaś na wątpliwość określoną w zawiązaniu sporu, choć termin ten nie do końca jest adekwatny dla procedury sądowo-administracyjnej, stwierdzając czy zaskarżony akt administracyjny jest nielegalny, a zatem nastąpiło violatio legis in procedendo lub in decernendo. W związku z tym decyzja orzeka też o ewentualnym naprawieniu szkód wynikłych z nielegalnego aktu administracyjnego ${ }^{50}$. Jak zatem zauważa A. Ranaudo, decyzja Sygnatury Apostolskiej nie ogranicza się do stwierdzenia nielegalności obiektywnej aktu administracyjnego, ale dotyka jego komponentów podmiotowych, jak i samej jego formy ${ }^{51}$.

\footnotetext{
${ }^{48}$ Por. Normae speciales, art. $120 \S 1$.

${ }^{49}$ Por. Normae speciales, art. $123 \S$ 1-3; J. KRUKOwsKI, dz. cyt., s. 244.

${ }^{50}$ Por. P. HAWYARD, Changes in ecclesiastical administrative justice brought about by the new competence of the "Sectio altera» of the Apostolic Signatura to award damages, Ius Ecclesiae 5, 1993, s. 643-673.

51 Por. A. RANAudo, Il ricorso gerarchico e la rimozione e trasferimento dei parroci nel nuovo codice, w: Dilexir Iustitiam. Studia in honorem Aurelii Card. Sabattani, Città del Vaticano 1984, s. 518.
} 
Wyrok ma moc res iudicata i nie podlega apelacji ${ }^{52}$. Należy jednak zauważyć, że zgodnie z kan. $1622,2^{\circ} \mathrm{KPK}^{53}$ wyrok jest dotknięty wadą nieważności usuwalnej jeśli nie zawiera motywów czyli racji decyzji. Co prawda art. 122 Norm specjalnych Sygnatury Apostolskiej stwierdza, iż decyzja Kolegium uzyskuje swoją moc prawną, chociażby nie zawierała motywów prawnych i faktycznych ${ }^{54}$, to jednak zdaniem autorów artykuł ten został uchylony przez kan. $1622,2{ }^{\circ} \mathrm{KPK}$. Oznacza to, że jeśli idzie o złożenie skragi o nieważność decyzji Sygnatury Apostolskiej, jak i prośby o przywrócenie do stanu poprzedniego, nie można tych środków wykluczyć, a zatem podmiot rekursu ma prawo z nich skorzystać ${ }^{55}$. Potwierdza to zarówno Z. Grocholewski ${ }^{56}$, jak i F. D'Ostilio ${ }^{57}$.

W tym względzie P.V. Pinto wyraża jednak opinię odmienną i stwierdza, że skoro decyzja ostateczna Kolegium nie podlega apelacji, nie może być też przedmiotem skargi o jej nieważność (querela), jak i prośby o przywrócenie do stanu poprzedniego (restitutio in integrum). Autor jest zdania, że ewentualna prośba o przywrócenie do stanu poprzedniego może być jedynie złożona bezpośrednio do Biskupa Rzymskiego.

${ }^{52}$ Por. Z. Grocholewski, La Sectio Altera, dz. cyt., s. 103.

${ }^{53}$ Kan. $1622,2^{\circ}$ brzmi: ,Sententia vitio sanabilis nullitatis dumtaxat laborat, si: $2^{\circ}$ motiva seu rationes decidendi non continet".

${ }^{54}$ Art. $122 \S 2$ brzmi: „Decisio vim suam habet, quamvis retiones in facto et in iure non contineat".

${ }^{55}$ Por. Z. Grocholewski, La Segnatura Apostolica nell'attuale fase di evoluzione, w: Dilexit iustitiam: Studia in honorem Aurelii Card. Sabattani, Città del Vaticano 1984, s. 218-219; J. Llobel, Note sull'impugnabilità delle decisioni della Segnatura Apostolica, Ius Ecclesiae 5, 1993, s. 675-698; G.P. MonTINI, De querela nullitatis deque restitutione in integrum adversus sententias Sectionis Alterius Supremi Signaturae Apostolicae Tribunalis, Periodica 82, 1993, s. 669-697.

${ }^{56}$ Por. Z. Grocholewski, La Sectio Altera, dz. cyt., s. 103. Autor jest zdania, że jakkolwiek Normy szczególne zdają się wykluczać taką możliwość, to jednak należy przyjąć, że decyzja Sygnatury Apostoslskiej może być przedmiotem zarówno skargi o jej nieważność, jak i restitutio in integrum, zgodnie z kan. 1892-1897 i 1905-1907 KPK.

${ }^{57}$ Por. F. D’OstiLio, dz. cyt., s. 526-527. Zdaniem tego autora, jakkolwiek decyzja Sygnatury Apostolskiej oznacza, że skarga przeszła w stan rzeczy osądzonej, a zatem nie może podlegać apelacji, pozostaje jednak możliwość wniesienia rekursu nadzwyczajnego do Biskupa Rzymskiego, jak i wniesienia skargi o nieważnośc decyzji oraz restitutio in integrum. 
Swoją opinię opiera na zasadzie, w myśl której sentencje Najwyższego Trybunału nie podlegają dyskusji ${ }^{58}$. Podobną opinię w przeszłości wyrazili zarówno I. Gordon ${ }^{59}$, D. Staffa ${ }^{60}$, jak i E. Labandeira ${ }^{61}$.

J. Krukowski stwierdza natomiast, że brak formalnego wymogu zamieszczenia motywacji jest wyjątkiem od ogólnej zasady, jaką stawia Kodeks Prawa Kanonicznego, aby każdy wyrok sądowy zawierał motywację swoich wyroków. Autor wskazuje jednak, że zamieszczenie takich motywacji jest przede wszystkim pożyteczne zarówno dla osoby wnoszącej rekurs, jak i dla organu administracji kościelnej, do którego należy wykonanie decyzji. Ponadto, jak zauważa autor, w praktyce Sygnatura Apostolska podaje motywacje swoich wyroków ${ }^{62}$.

Przychylając się do zdania większości autorów należy uznać, że decyzja Kolegium Sygnatury Apostolskiej jakkolwiek nie podlega apelacji, może być przedmiotem skargi o nieważność, jak i prośby o przywrócenie do stanu poprzedniego. Ponadto zawsze istnieje możliwość wniesienia rekursu do Papieża z prośbą o ponowne rozpatrzenie sprawy ${ }^{63}$.

Decyzja Kolegium rozstrzygająca spór winna być zredagowana przez kardynała ponensa, podpisana przez członków Kolegium i natychmiast przekazana Sekretarzowi ${ }^{64}$.

Powiadomienie zainteresowanych stron o decyzji Kolegium dokonuje się, w myśl kan. 1615 KPK z 1983 r. albo przez wręczenie decyzji

${ }^{58}$ Por. P.V. PinTo, dz. cyt., s. 383.

${ }^{59}$ Por. I. Gordon, Normae Speciales Supremi Tribunalis Signaturae Apostolacie: editio aucta introductione, fontibus et notis, Periodica 59, 1970, s. 162.

${ }^{60}$ Por. D. Staffa, De Supremo Tribunali Administrativo seu de Secunda Sectione Supremi Tribunalis Signaturae Apostolicae, Periodica 61, 1971, s. 28.

${ }^{61}$ Por. E. LabandeIRA, El procedimento contencioso-administrativo ante la Signatura Apostolica, Ius Canonicum 43, 1982, s. 259.

${ }^{62}$ Por. J. Krukowski, dz. cyt., s. 244-245.

${ }^{63}$ Por. F. Salerno, dz. cyt., s. 175. Autor zauważa, że doświadczenie uczy, iż nie brakuje rekursów do Biskupa Rzymskiego. Nie zawsze jednak dotyczą one prośby o zmianę decyzji Sygnatury Apostolskiej, gdyż często zawieraja prośbę o możliwość wniesienia rekursu po upływie przewidzianych przez prawo terminów lub o przyjęcie rekursu pomimo oddalenia go przez Kongres. Co należy podkreślić decyzja Biskupa Rzymskiego w tym względzie ma charakter łaski i zależy wyłącznie od jego dyskrecjonalnej władzy.

${ }^{64}$ Por. Normae speciales, art. 121. 
stronom lub ich pełnomocnikom albo przez przesłanie im egzemplarza decyzji ${ }^{65}$. Przesłanie egzemplarza decyzji zaś, zgodnie z kan. 1509 KPK, powinno być dokonane przez pocztę lub w inny sposób, który jest najpewniejszy.

\section{Wykonanie i skutki decyzji II sekcji Sygnatury Apostolskiej}

Decyzja ostateczna II sekcji Sygnatury Apostolskiej wywołuje określone skutki prawne wobec osób uczestniczących w procesie w charakterze stron. Jeśli rekurs został uznany jako pozbawiony fundamentu, mamy do czynienia z uznaniem legalności zaskarżonego aktu administracyjnego, co nie do końca jest jednoznaczne $\mathrm{z}$ jego potwiedzeniem, gdyż Sygnatura, w ramach przyznanej jej kompetencji, wypowiada się wyłącznie w kwestii stanowiącej przedmiot postępowania. Oznacza to, że decyzja stwierdzająca legalność aktu administracyjnego stanowi jedynie tytuł do jego wykonania ${ }^{66}$.

Jeśli rekurs rozpatrywany w II sekcji Sygnatury Apostolskiej zakończy się decyzją uznającą zaskarżony akt administracyjny za nielegalny, akt ten zostanie anulowany w całości lub w części. Decyzja Sygnatury Apostolskiej wywołuje skutki ex tunc, a zatem przywraca sytuację prawną podmiotów do momentu, przed wydaniem orzeczonego jako nielegalny aktu administracyjnego. Należy jednak dodać, że nie zawsze przywrócenie sytuacji prawnej sprzed wydania aktu jest możliwe wyłącznie w oparciu o orzeczenie danego aktu jako nielegalny, gdyż czasami konieczne jest w tym względzie wydanie kilku innych aktów administracyjnych ${ }^{67}$.

Decyzja II sekcji uznająca nielegalność zaskarżonego aktu nakazuje organowi władzy administracyjnej, będącemu autorem aktu, obowiązek dostosowania sytuacji prawnej i faktycznej do dyspozy-

\footnotetext{
${ }^{65}$ Kan. 1615 brzmi: „Publicatio seu intimatio sententiae ferii potest vel tradendo exemplar sententiae partibus aut larum procuratoribus, vel eisdem transmittendo idem exemplar ad normam can. 1509".

${ }^{66}$ Por. A. Sabattani, Iudicium de legitimitate actuum administrativorum a Signatura Apostolica peractum, Ius Canonicum 16, 1976, s. 232.

${ }^{67}$ Por. S.F. Aumenta, La tutela dei diritti dei fedeli nel processo contenzioso amministrativo canonico, Roma 1999, s. 164.
} 
cji wyroku. Jeżeli zaskarżony akt administracyjny został anulowany w całości, wtedy organ władzy administracyjnej zobowiązany jest do wydania nowego aktu. Jeśli zaś akt administracyjny został anulowany tylko w części, wtedy organ administracyjny może go zmienić częściowo zgodnie z decyzją II Sekcji. Jeśli zaś przedmiotem rekursu była odmowa wydania aktu administracyjnego, wtedy organ administracyjny może być zobowiązany do wydania takiego aktu ${ }^{68}$.

Co do procedury wykonania decyzji II Sekcji Sygnatury Apostolskiej należy zauważyć, że brak jest w tej kwestii szczegółowych norm. W tym względzie G.P. Montini używa nawet terminu lacuna iuris ${ }^{69}$. Brak ten jest wyczuwalny szczególnie w sytuacji, gdy organ administracyjny, będący autorem orzeczonego jako nielegalny aktu administracyjnego, nie przystąpi do jego wykonania, które przecież zakłada nie tylko przyjęcie bierne decyzji, ale też podjęcie stosownych kroków w postaci dekretów czy innych aktów przywracających sytuację prawną i faktyczną adresata aktu sprzed jego wydania. Nie ma w tym względzie też i norm, które mogły spowodować przynaglenie organu administracyjnego czy też zmuszenie go do podjęcia działania ${ }^{70}$.

Mówiąc o przynagleniu organu administracyjnego do podjęcia działania G.P. Montini wskazuje na kilka możliwych sposobów działania. Wyróżnia pośród nich te, które jego zdaniem można zastosować w odniesneiu do decyzji Sygnatury Apostolskiej i te, które mogą jedynie pomóc w wykonaniu jej decyzji. Do pierwszej grupy autor zalicza rekurs administracyjny, a więc najpierw hierarchiczny, a następnie do II Sekcji Sygnatury Apostolskiej, w oparciu o violatio legis polegające na niewykonaniu decyzji Sygnatury Apostolskiej, oraz proces sądowy o niewykonanie wyroku, w oparciu o normę zawartą w kan. 1650 § 1 KPK. Jak wskazuje Autor, jakkolwiek ta druga droga nie do końca jest wskazana dla procedur administracyjnych, to jednak praktyka Sygnatury Apostolskiej wskazuje na możliwość jej zastosowania w odnie-

\footnotetext{
${ }^{68}$ Por. J. KRUKOwsKi, dz. cyt., s. 247.

${ }^{69}$ Por. G.P. Montini, L'esecuzione delle sentenze della "Sectio Altera" della Segnatura Apostolica, w: Iustus Iudex, Essen 1990, s. 555-571.

${ }^{70}$ Por. F. SAlERNo, dz. cyt., s. 177.
} 
sieniu do jej decyzji. Jako środki mogące pomóc wyegzekwowaniu od organu administracyjnego wykonania decyzji orzekającej zaskarżony akt jako nielegalny G.P. Montini wskazuje na prośbę do Biskupa Rzymskiego, zwykły proces sądowy oraz postępowanie dyscyplinarne względem organu, który odmawia wykonania wyroku ${ }^{71}$.

Wydaje się, że istotne znaczenie dla skuteczności decyzji II sekcji Sygnatury Apostolskiej ma norma zawarta w art. $123 \S 2$ Konstytucji Apostolskiej Pastor Bonus, dotycząca możliwości złożenia przez adresata zaskarżonego aktu administracyjnego prośby o naprawienie szkód wynikających z nielegalności tegoż aktu. Norma ta $\mathrm{z}$ oczywistych względów, o czym była już mowa, ma swoje zastosowanie w sytuacji, gdy Sygnatura Apostolska zaskarżony akt orzeknie jako nielegalny ${ }^{72}$.

W tym miejscu należy zauważyć, że w myśl kan. 1654-1655 KPK, każdy, kto zobowiązany jest do wykonania jakiegoś wyroku cieszy się określoną dyskrecjonalnością. Dotyczy ona przede wszytkim interpretacji tekstu wyroku, ale też sposobów i czasu jego wykonania. Należy zauważyć, że oprócz wskazanych aspektów dyskrecjonalności wykonania wyroku, w odniesieniu do organu administracyjnego zobowiązanego do wykonania sentencji II sekcji Sygnatury Apostolskiej, trzeba wziąc pod uwagę jeszcze jeden niezwykle istotny. Nie bez znaczenia jest bowiem, że organ administracyjny, pomimo decyzji orzekającej nielegalność wydanego przez niego aktu nadal posiada władzę wykonawczą $\mathrm{w}$ stosunku do adresata aktu, zatem może podejmować stosowne decyzje i wydawać nowe akty administracyjne dotyczące tegoż adresata $^{73}$.

${ }^{71}$ Por. G.P. Montins, L'esecuzione delle pronunce giudiziali Della Segnatura Apostolica nel contenzioso amministrativo, w: La giustizia nell'attività amministrativa della Chiesa: il contenzioso amministrativo, Milano 2006, s. 396-404.

${ }^{72}$ Por. tamże, s. 395.

${ }^{73}$ Por. tamże, s. 408. 


\section{The procedure of recourse do the II section of Sygnature Apostolic}

In accord with the can. $221 \S 1$ of Code of Canon Law the Christian faithful can legitimately vindicate and defend the rights which they enjoy in the Church before a competent ecclesiastical court in accord with the norm of law. In this article the author is trying to explane the main norms of the the procedure of recourse do the II section of Sygnature Apostolic.

SŁowA KLUCZowE: rekurs, Sygnatura Apostolska

KEY wORDS: recourse, Sygnature Apostolic 